\title{
THE IMPACT OF GENDER, LEVEL DEGREE OF EDUCATION AND THE AMOUNT OF SALARY ON THE SATISFACTION WITH LIFE AND POLITICAL CULTURE- AN EXAMPLE OF SLOVENIA
}

\author{
Mr. Anton Vorina, Professor, Vocational College of Economics, Celje, Slovenija, e-mail: \\ anton.vorina@guest.arnes.si
}

Nina Vorina, Student of Faculty of Education, Koper, Slovenija, e-mail: nina.vorina@ siol.net

\begin{abstract}
In this paper we analyzed the impact of gender, degree of education and the amount of salary in the satisfaction with life and political culture on example in Slovenia. The main goal of the research is to determine whether (and how) the impact of gender, level of education and the amount of salary on the satisfaction with life and political culture. A written "online" survey (with Google-drive) was conducted from 25/4/2013 to 7/5/2013. We observe that there are statistically significant differences among the respondents with different degree of education $(\mathrm{p}$-value $=0.003)$ and amount of salary $(\mathrm{p}$ value $=0.002)$ regarding the satisfaction with life. We found out that there isn't statistically significantly different between satisfaction with life and gender. We also found out that there are statistically significant differences among the gender ( $\mathrm{p}$-value $=0.007)$ and respondents with different amount of salary ( $\mathrm{p}$-value $=0.002$ ) regarding the satisfaction with political culture. The respondents with highest amount of salary are more satisfied with life than the respondents with the lowest amount of salary.
\end{abstract}

Keywords: satisfaction with life, political culture, salary, gender, level of education.

\section{Introduction}

The following research study, considered the following six questions: Is there a statistically significant difference in the satisfaction with life between gender? Is there a statistically significant difference in the satisfaction with life between respondents with different degree of education? Is there a statistically significant difference in the satisfaction with life between respondents with different amount of salary? Is there a statistically significant difference in the satisfaction with political culture between gender? Is there a statistically significant difference in the satisfaction with political culture between respondents with different degree of education? Is there a statistically significant difference in the satisfaction with political culture between respondents with different amount of salary?

\section{We're assuming:}

Hypothesis 1: There is a statistically significant difference in the satisfaction with life between gender. Hypothesis 2: There is a statistically significant difference in the satisfaction with life between respondents with different degree of education. Hypothesis 3: There is a statistically significant difference in the satisfaction with life between respondents with different amount of salary. Hypothesis 4: There is a statistically significant difference in the satisfaction with political culture between gender. Hypothesis 5: There is a statistically significant difference in the satisfaction with political culture between respondents with different degree of education. Hypothesis 6: There is a statistically significant difference in the satisfaction with political culture between respondents with different amount of salary.

Research data has been acquired through the use of a questionnaire. For data exploration using Excel, Megastat, IBM SPSS 20. We used descriptive analysis and test ANOVA.

\section{Literature overview}

Satisfaction is a pleasant emotion associated with quality of life. Otherwise, you can survive without the satisfaction and happiness but that life is a miserable and without any real quality. People are looking for satisfaction and they strive for satisfaction and happiness. It is very important that we feel satisfied, fulfilled and happy.

There is a lot of research on satisfaction with life (hereinafter referred to as SWL) or well-being but there is no research about satisfaction with political culture (hereinafter referred to as SWPC) and also relationship between them.

"Happiness" began gaining standing as a field in economics in the 1970s, particularly 
with the work of Easterlin (1974, Kacapyr, 2008).

Oswald (1997) reports the general conclusions of country-specific studies: income contributes, but only marginally, to happiness; unemployment lowers happiness dramatically; happiness is positively related to marriage, education, being female, being white and being self-employed; happiness declines until an adult reaches age 30 and then begins to increase with age.

Borooah's (2006) study indicates that self-reported happiness depends on faith in a deity; income; employment; family and social life; and good health.

Easterlin (1995) finds that income is not a significant determinant of happiness in the USA with a correlation coefficient of 0.2.

Kacapyr (2008) finds that social and economic factors explain about $66 \%$ of the variance in self-reported happiness across nations. Respondents in former socialist-bloc countries report surprisingly low levels of SWL given their circumstances while Latin Americans report higher-than-expected levels of happiness.

The Satisfaction With Life Scale (SWLS) is a global measure of happiness, defined as the cognitive, judgmental component of satisfaction with life. Research indicates that job satisfaction is significantly related to life satisfaction. Since the 1930's there has been a great deal of interest in the relationship between employee well-being andproductivity. Hersey (1932, Zelenski et. al, 2008) reported a positive relationship between daily emotions and performance.

According to research in November $2010,85 \%$ of the people in Slovenia were satisfied with their lives, of which $21 \%$ were very satisfied. Very dissatisfied were $3 \%$ of people in Slovenia (http://www.stat.si/, Vorina, Škafar, 2013).

Political culture is defined by the International Encyclopedia of the Social Sciences as "the set of attitudes, beliefs and sentiments which give order and meaning to a political process and which provide the underlying assumptions and rules that govern behaviour in the political system." It encompasses both the political ideals and operating norms of a polity. Political culture is thus the manifestation in aggregate form of the psychological and subjective dimensions of politics. A political culture is the product of both the collective history of a political system and the life histories of the members of the system and thus it is rooted equally in public events and private experience." (Freedman, 1986)

A political culture is a set of attitudes and practices held by a person that shapes their political behaviuor. It includes moral judgments, political myths, feelings, and thoughts about what makes for a just society. A political culture is a reflection of a government, but it also incorporates elements of history and tradition that may precede the current regime. Political cultures matter because they determine a population's political perception and actions. Governments can help shape political culture and public opinion through education, public events, and commemoration of the past. Political cultures vary greatly from state to state and sometimes even within a state. Generally speaking, however, political culture remains more or less the same over time.

Example: The United States and Great Britain are both democracies, but each holds a distinct political culture. The American government derives its powers from a written constitution drafted by men who feared monarchs and strong central governments, which is why they divided the federal government into three distinct branches. Likewise, the American political system is dominated by two political parties. Great Britain, in contrast, has a long history of the monarchy and has never had a written constitution. Even though the current monarch has the official title of the head of state, her powers are nominal, leaving Parliament-the legislative body - as the dominant component of the government. And unlike the United States, Great Britain currently has nearly half a dozen political parties that regularly seat candidates in Parliament (http://www.sparknotes.com/usgovernment-and-politics/politicalscience/political-culture-and-publicopinion/section1.rhtml).

One of the biggest challenges for the study of politics is the questions: Does political participation lead to happiness or not? Research in this area has been made on the theory in which the focus on co-operation of democratic politics and life satisfaction. The research indicates that people are not happier because they are participating in politics 
(http://www.iadb.org/res/publications/pubfiles/p ubWP-638.pdf).

\section{Exploratory data analysis}

Sample. We chose to investigate the population-people (from 15 to 99 years old) from Slovenia. Occasional sample consisted of 1149 respondents. The study included 465 (40.5 $\%)$ men and $684(59.5 \%)$ women. There were 49 people (4.3 \%) with completed primary school degree of education or less, 591 respondents $(51.4 \%)$ with completed secondary school degree of education and 509 people (44.3 $\%)$ with completed vocational school degree of education or more. There were 294 people $(60.4$ $\%$ ) with the amount of salary from $600^{15}$ euros to $997^{16}$ euros and 193 people $(39.6 \%)$ with the salary above 998 euros. 662 respondents didn't answer this question.

Accessories-description questionnaire. The questionnaire consisted of 13 claims or questions which have been divided into three sections. The first section consisted of three demographic data (gender, salary or income, degree of education) and the second set consisted of five factors about SWL. The satisfaction with life (SWL) was measured by SWLS consists of 5-items: In most ways my life is close to my ideal; The conditions of my life are excellent; I am satisfied with my life; So far I have gotten the important things I want in life; If I could live my life over, I would change almost nothing. The assessment scale had a 5 points: 5 - Strongly agree; 4 - Agree; 3 - Neither agree nor disagree; 2 - Disagree; 1 - Strongly disagree. The satisfaction with political culture (SWPC) was measured by 5 items: I have utter confidence in the government and its work; Politicians are honest; The government is working hard to do well for a citizen; Legal order and principle of a state governed by the rule of law are respected in our country; Our president is an honorable person. The assessment scale had a 5 points: 5 - Strongly agree; 4 - Agree; 3 - Neither agree nor disagree; 2 - Disagree; 1 - Strongly disagree. A written "online" survey (with Google-drive) was conducted from 25/4/2013 to 7/5/2013.

\footnotetext{
${ }^{15}$ Net minimum wage-salary in Slovenia is 599.73 EUR (year 2013).

${ }^{16}$ Average net wage-salaryin May 2013 was 997.13 EUR.

Used methods, data processing. The collected data were analyzed using IBM SPSS, version 20. We have also used the Microsoft tools Word and Excel. Regarding the purpose and objectives of the research we used descriptive statistics and ANOVA test.

The reliability of a questionnaire, which measure SWL is Cronbach's alpha 0.861 (Tables 1 and 2), the reliability of a questionnaire, which measure satisfaction with political culture (SWPC) is Cronbach's alpha 0.802 which means a lot or exemplary reliability of measurement.

Table 1. Case Processing Summary, SWL

\begin{tabular}{|r|c|c|}
\hline & $\mathrm{N}$ & $\%$ \\
\hline Valid & 1149 & 100 \\
\hline Cases excluded & 0 & 0 \\
\hline Total & 1149 & 100 \\
\hline
\end{tabular}

Source: SPSS 20, Author's creation

Table 2. Reliability Statistics, SWL

\begin{tabular}{|c|c|}
\hline Cronbach's Alpha & N of items \\
\hline 0.861 & 5 \\
\hline
\end{tabular}

Source: SPSS 20, Author's creation

Table 3. Case Processing Summary, SWPC

\begin{tabular}{|r|c|c|}
\hline & $\mathrm{N}$ & $\%$ \\
\hline Valid & 1149 & 100 \\
\hline Cases excluded & 0 & 0 \\
\hline Total & 1149 & 100 \\
\hline
\end{tabular}

Source: SPSS 20, Author's creation

Table 4. Reliability Statistics, SWPC

\begin{tabular}{|c|c|}
\hline Cronbach's Alpha & N of items \\
\hline 0.802 & 5 \\
\hline
\end{tabular}

Source: SPSS 20, Author's creation 


\section{Findings of the research-test hypotheses}

The first hypothesis states there is a statistically significant difference in the satisfaction with life between gender. SWL was measured as a summary of five items as noted above.

Table 5 we can see $(F(1,1148)=3.840$, p-value $=0.05$ ), that there isn't a statistically significant difference in the satisfaction with life between gender. Therefore the first hypothesis is rejected.

Table 5. Test ANOVA-SWL and gender

\begin{tabular}{|c|c|c|c|c|c|}
\hline & $\begin{array}{c}\text { Sum of } \\
\text { Squares }\end{array}$ & df & $\begin{array}{c}\text { Mean } \\
\text { Squar } \\
\mathrm{e}\end{array}$ & $\mathrm{F}$ & $\begin{array}{c}\text { P- } \\
\text { valu } \\
\mathrm{e}\end{array}$ \\
\hline $\begin{array}{c}\text { Between } \\
\text { Groups }\end{array}$ & 78.516 & 1 & 78.51 & 3.840 & 0.05 \\
\hline $\begin{array}{c}\text { Within } \\
\text { Groups }\end{array}$ & 23454.8 & 1147 & 20,45 & & \\
\hline Total & 23533.3 & 1148 & & & \\
\hline
\end{tabular}

Source: IBM SPSS 20, Excel, Author's creation

The second hypothesis states there is a statistically significant difference in the satisfaction with life between respondents with different degree of education.

Table 6 we can see $(F(20,1148)=$ $1.715, \mathrm{p}$-value $=0.003$ ), that there is a statistically significant difference between the satisfaction with life and respondents with different degree of education. Therefore the second hypothesis is accepted.

It may be noted (Table 7) that there is a statistically significant difference in the SWL between the respondents who completed secondary school and those who completed vocational college or more ( $p$-value $=0.002)$.
Table 6. Test ANOVA-SWL and degree of education

\begin{tabular}{|c|c|c|c|c|c|}
\hline & $\begin{array}{c}\text { Sum of } \\
\text { Squares }\end{array}$ & df & $\begin{array}{c}\text { Mean } \\
\text { Square }\end{array}$ & F & $\begin{array}{c}\text { P- } \\
\text { value }\end{array}$ \\
\hline $\begin{array}{c}\text { Between } \\
\text { Groups }\end{array}$ & 240.320 & 2 & 120.16 & 5.912 & 0.003 \\
\hline $\begin{array}{c}\text { Within } \\
\text { Groups }\end{array}$ & 23293.0 & 1146 & 20.325 & & \\
\hline Total & 23533.3 & 1148 & & & \\
\hline \multicolumn{7}{c}{ Source: IBM SPSS 20, Excel, Author's } \\
creation
\end{tabular}

Table 7. Bonferroni correction- SWL and degree of education

\begin{tabular}{|l|l|c|c|c|}
\hline $\begin{array}{l}\text { (I) Degree of } \\
\text { education }\end{array}$ & $\begin{array}{l}\text { (J) Level of } \\
\text { education }\end{array}$ & Mean & $\begin{array}{c}\text { Std. } \\
\text { Error }\end{array}$ & P-value \\
\hline \multirow{2}{*}{$\begin{array}{l}\text { Primary } \\
\text { school or less }\end{array}$} & $\begin{array}{l}\text { Secondary } \\
\text { school }\end{array}$ & 0.447 & 0.670 & 1.000 \\
\cline { 2 - 5 } & $\begin{array}{l}\text { Vocational } \\
\text { College or } \\
\text { more }\end{array}$ & -0.490 & 0.674 & 1.000 \\
\hline \multirow{2}{*}{$\begin{array}{l}\text { Secondary } \\
\text { school }\end{array}$} & $\begin{array}{l}\text { Primary } \\
\text { school or less }\end{array}$ & $-0 ., 447$ & 0.670 & 1.000 \\
\cline { 2 - 5 } & $\begin{array}{l}\text { Vocational } \\
\text { College or } \\
\text { more }\end{array}$ & $-0.937^{*}$ & 0.273 & 0.002 \\
\hline \multirow{3}{*}{$\begin{array}{l}\text { Vocational } \\
\text { College or } \\
\text { more }\end{array}$} & $\begin{array}{l}\text { Primary } \\
\text { school or less }\end{array}$ & 0.490 & 0.674 & 1.000 \\
\cline { 2 - 5 } & $\begin{array}{l}\text { Secondary } \\
\text { school }\end{array}$ & $0.937^{*}$ & 0.273 & 0.002 \\
\hline
\end{tabular}

The third hypothesis states there is a statistically significant difference in the satisfaction with life between respondents with different amount of salary.Table 8 we can see (F $(1,486)=9.341, p$-value $=0.002)$, that there is a statistically significant difference in the satisfaction with life between respondents with different amount of salary. Therefore the third hypothesis is accepted. 
(JPMNT) Journal of Process Management - New Technologies, International

Vol. 1, No.4, 2013.

Table 8. Test ANOVA- SWL and amount of salary

\begin{tabular}{|c|c|r|r|r|c|}
\hline & $\begin{array}{c}\text { Sum of } \\
\text { Squares }\end{array}$ & df & $\begin{array}{c}\text { Mean } \\
\text { Square }\end{array}$ & F & $\begin{array}{c}\text { P- } \\
\text { value }\end{array}$ \\
\hline $\begin{array}{c}\text { Between } \\
\text { Groups }\end{array}$ & 167.841 & 1 & 167.84 & 9.341 & 0.002 \\
\hline $\begin{array}{c}\text { Within } \\
\text { Groups }\end{array}$ & 8714.34 & 485 & 17.968 & & \\
\hline Total & 8882.18 & 486 & & & \\
\hline \multicolumn{5}{|c|}{ Source: IBM SPSS 20, Excel, Author's } \\
creation
\end{tabular}

Table 9. Mean - SWL and amount of salary

\begin{tabular}{|c|c|c|c|}
\hline Salary & Mean & $\mathrm{N}$ & $\begin{array}{c}\text { Std. } \\
\text { Deviation }\end{array}$ \\
\hline From 600 to 997 & 15.21 & 294 & 4.305 \\
\hline Above 998 & 16.41 & 193 & 4.136 \\
\hline Total & 15.69 & 487 & 4.275 \\
\hline \multicolumn{2}{|c|}{ Source: IBM SPSS 20, Excel, Author's } \\
creation
\end{tabular}

Respondents $(\mathrm{M}=16.41, \mathrm{SD}=4.136)$ with salary highest then 998 euros are more SWL then the respondents $(\mathrm{M}=15.21, \mathrm{SD}=4.305)$ having a lower salary (from 597 to 997 euros).

The fourth hypothesis states there is a statistically significant difference in the satisfaction with political culture between gender. SWPC was measured as a summary of five items as noted above.

Table 10 we can see $(\mathrm{F}(1,1148)=7.221$, pvalue $=0.007$ ), that there is a statistically significant difference between the satisfaction with political culture and gender. Therefore the fourth hypothesis is accepted.

Table 10. Test ANOVA- SWPC and gender

\begin{tabular}{|c|r|r|r|r|r|}
\hline & $\begin{array}{c}\text { Sum of } \\
\text { Squares }\end{array}$ & df & $\begin{array}{c}\text { Mean } \\
\text { Square }\end{array}$ & F & P-value \\
\hline $\begin{array}{c}\text { Between } \\
\text { Groups }\end{array}$ & 74.538 & 1 & 74.538 & 7.221 & 0.007 \\
\hline $\begin{array}{c}\text { Within } \\
\text { Groups }\end{array}$ & 11839.7 & 1147 & 10.322 & & \\
\hline Total & 11914.2 & 1148 & & & \\
\hline
\end{tabular}

Source: IBM SPSS 20, Excel, Author's creation
Table 11: Mean - SWPC and gender

\begin{tabular}{|c|c|c|c|}
\hline Gender & Mean & $\mathrm{N}$ & $\begin{array}{c}\text { Std. } \\
\text { Deviation }\end{array}$ \\
\hline Men & 8.63 & 465 & 3.403 \\
\hline Women & 8.12 & 684 & 3.077 \\
\hline Total & 8.33 & 1149 & 3.222 \\
\hline
\end{tabular}

Source: IBM SPSS 20, Excel, Author's creation

Men $(M=8.63, S D=3.403)$ are more SWPC then the women $(\mathrm{M}=8.12, \mathrm{SD}=3.077)$.

The fifth hypothesis states there is a statistically significant difference in the satisfaction with political culture between respondents with different degree of education.

Table 11 we can see $(F(2,1148)=$ $0.433, \mathrm{p}$-value $=0.649)$, that there isn't a statistically significant difference in the satisfaction with political culture and respondents with different degree of education. Therefore the fifth hypothesis is rejected.

Table 11. Test ANOVA-SWPC and level of degree

\begin{tabular}{|c|c|c|c|c|c|}
\hline & $\begin{array}{c}\text { Sum of } \\
\text { Squares }\end{array}$ & df & $\begin{array}{c}\text { Mean } \\
\text { Square }\end{array}$ & F & P-value \\
\hline $\begin{array}{c}\text { Between } \\
\text { Groups }\end{array}$ & 8.994 & 2 & 4.497 & 0.433 & 0.649 \\
\hline $\begin{array}{c}\text { Within } \\
\text { Groups }\end{array}$ & 11905.3 & 1146 & 10.389 & & \\
\hline Total & 11914.3 & 1148 & & & \\
\hline
\end{tabular}

Source: IBM SPSS 20, Excel, Author's

creation

The sixth hypothesis states there is a statistically significant difference in the satisfaction with political culture between respondents with different amount of salary.

Table 12 we can see $(F(1,486)=10.03$, $\mathrm{p}$-value $=0.002)$, that there is a statistically significant difference in the satisfaction with political culture and respondents with different level of earnings. Therefore the sixth hypothesis is accepted. 
Table 12: Test ANOVA-SWPC and amount of salary

\begin{tabular}{|c|c|c|c|c|c|}
\hline & $\begin{array}{c}\text { Sum of } \\
\text { Squares }\end{array}$ & df & $\begin{array}{c}\text { Mean } \\
\text { Square }\end{array}$ & F & $\begin{array}{c}\text { P- } \\
\text { value }\end{array}$ \\
\hline $\begin{array}{c}\text { Between } \\
\text { Groups }\end{array}$ & 107.823 & 1 & 107.8 & 10.03 & 0.002 \\
\hline $\begin{array}{c}\text { Within } \\
\text { Groups }\end{array}$ & 5215.9 & 485 & 10.755 & & \\
\hline Total & 5323.8 & 486 & & & \\
\hline \multicolumn{7}{|c|}{ Source: IBM SPSS 20, Excel, Author's } \\
creation
\end{tabular}

Table 13: Mean - SWPC and amount of salary

\begin{tabular}{|c|c|c|c|}
\hline Salary & Mean & $\mathrm{N}$ & $\begin{array}{c}\text { Std. } \\
\text { Deviation }\end{array}$ \\
\hline From 600 to 997 & 9.11 & 294 & 3.466 \\
\hline Above 998 & 8.15 & 193 & 2.973 \\
\hline Total & 8.73 & 487 & 3.310 \\
\hline \multicolumn{3}{|c|}{ Source: IBM SPSS 20, Excel, Author's } \\
creation
\end{tabular}

Respondents $(\mathrm{M}=9.11, \mathrm{SD}=3.466)$ who have the salary from 597 to 997 euros are more SWPC then the respondents $(\mathrm{M}=8.15, \mathrm{SD}=2.937)$ who havethe highest salary (above 998 euros).

\section{Conclusion}

In the paper we investigate the SWL and SWPC on occasional sample 1149 citizens from Slovenia.

In our research, we found out that there is a statistically significant difference in the SWL between respondents with different degree of education and the amount of salary.

We also discovered that there is a statistically significant difference in the SWPC between gender and amount of salary.

There is a positive correlation between the amount of salary and SWL. The respondents who have the highest (above 998 euros) amount of salary are more SWL then the respondents who have the lowest salary (from 600 to 997 euros).

There is a negative correlation between the amount of salary and SWPC. The respondents who have the lowest salary (from 597 to 997 euros) are more SWPC then the respondents who have the highest salary (above 998 euros).

But, unfortunately, we found out that the citizens in Slovenia are not SWPC at all $(\mathrm{M}=8.33, \mathrm{MIN}=5, \mathrm{MAX}=25)$.

We have to change the political culture at the highest level!

\section{References}

1. Borooah, V.K. (2006) How much happiness is there in the world? A cross-country study, Applied Economics Letters, 13(8): 483-488.

2. Easterlin, R. (1995) Will raising the incomes of all increase the happiness of all? Journal of Economic Behavior \& Organization, 27(1): 3547.

3. Freedman, J. (1986) International Encyclopedia of the Social Sciences. New York: Macmillen.

4. Kacapyr, E. (2008) Cross-country determinants of satisfaction with life. International Journal of Social Economics, 35(6): 400-416.

5. Oswald, A. (1997) Happiness and economic performance. The Economic Journal, 107(445): 1815-1831.

6. Political culture and public opinion, http://www.sparknotes.com/us-government-andpolitics/political-science/political-culture-andpublic-opinion/section1.rhtml (28.9.2013).

7. Political Participation and Quality of Life, http://www.iadb.org/res/publications/pubfiles/pu bWP-638.pdf (30.9.2013).

8. Psychological Well-Being and Organizational Commitment: Exploration of the Relationship, http://www.amrita.edu/sdg/pdf/ASB\%20Workin g\%20paper\%20series/MBA\%20book\%201062011\%20Psychological\%20Well-

Being\%20and\%200rganizational\%20Commitme nt\%20Exploration\%200f\%20the\%20Relationshi p.pdf (1.10.2013).

9. The Happy-Productive Worker Thesis Revisited. http://www.sel.eesc.usp.br/informatica/graduaca o/material/etica/private/the_happyproductive_worker_thesis_revisited.pdf (1.10.2013)

10. Vorina, A. (2013) The relationship between satisfaction with life and employee engagement, Journal of Process Management - New Technologies, International, 1(2): 77-81.

11. Vorina, A. and B. Škafar. (2013) Zadovoljstvo z življenjem in politično kulturo $v$ Sloveniji in na Hrvaškem. Murska Sobota: Ekonomska šola, višja strokovna šola. 